UNIO - EU Law Journal. Vol. 5, No. 1, January 2019, pp 121-141.

(2019 Centre of Studies in European Union Law

School of Law - University of Minho

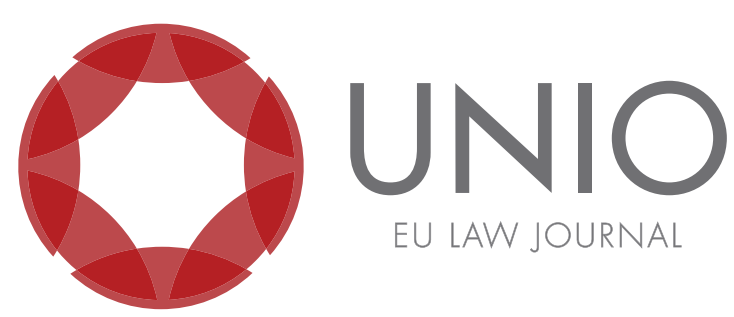

\title{
The situation of women in BRIC countries: a comparative analysis of the (in) effectiveness of public policies for the protection of women and reduction of gender inequality in the four largest emerging economies in the world
}

\author{
Diva Júlia Sousa Safe Coelho* \\ Ricardo Spindola Diniz** \\ Saulo de Oliveira Pinto Coelho***
}

ABSTRACT: The research consists of a comparative study of the concrete experiences of Russia, China, India and Brazil on the implementation of policies for the protection of women and reduction of gender inequality. From a constitutional perspective of analysis, it seeks to overcome the purely nomological or doctrinal comparison, typical of the classical view of Comparative Law, in favor of an experiences and realities comparison. To achieve this goal, it uses a complex set of data gathered from relevant reports on the subject in the international context, as well as, realizing a explorative study of the existing literature on the subject in each of the countries. As main results, it was verified that the four countries suffer from serious problems regarding the effectiveness of gender equality and the guarantee of women's dignity, freedom, and respect. However, each country faces specific challenges in dealing with the issue.

KEYWORDS: BRIC - women's rights - genre - legal comparison - public policies.

\footnotetext{
* Professor at the Federal University of Mato Grosso do Sul (UFMS), Brazil. PhD in Citizenship and Human Rights from the University of Barcelona with a full scholarship from CAPES (Brazilian Higher Education Agency).

** PhD candidate in Law at the University of São Paulo (USP), Brazil. Master's Degree in Philosophy of Law at the University of Brasilia (UnB), Brazil.

*** Coordinator of the Master's Degree in Law and Public Policy of the Federal University of Goiás (UFG), Brazil. Deputy Director of the Faculty of Law of UFG.
} 


\section{Introduction}

The current globalization, accelerating and unifying productive and technological processes, has made the problems of nations considered as emerging economies so close and shared, despite the possible mismatch of contexts and perspectives. It is imperative to point out that BRICS countries, the world's largest emerging economies, have common problems mainly due to the recent modernization processes in which they have been engaged. This does not mean that these problems are manifested and configured in an equal way, having in each case specific dynamics and challenges. This shared origin of the current problems faced by each one served as a guideline for the constitution of the Bloc, in the sense of seeking common strategies for solving common problems, with the aim of the continuity of socio-economic development. Nevertheless, the Bloc needs to have a reciprocal knowledge of the singular and peculiar contours that these problems, especially social and humanitarian ones, assume in each of these countries.

Inequality, oppression, discrimination and violence against women are certainly problems shared by Brazil, Russia, India and China (the BRICS founding countries). The comparative study developed here has resulted in a better understanding of the socio-political and institutional complexes that, in each of these four countries, shape the difficulties faced by women in recognizing their constitutionally declared rights in those States, and the inadequacies, contradictions and ineffectiveness that mark the public policies of protection and promotion of women in these nations.

It is necessary to know better the BRICS, beyond their economical dynamics. This includes knowing them better also in their legal, social and institutional dynamics and experiences. But to meet this cognitive demand, the development of abstract, merely nomological comparisons is not enough. Therefore, the critical contrast that was sought to be built in the present research, was by using research sources from the countries studied. This allows a double counterpoint: between the dimension of nomological discourse and the dimension of the experience of fundamental rights in practice (in this case, the actual dimension of women's rights and their disrespect); and, on the other hand, the contrast between the Eurocentric, external view of these problems and the critical narratives developed in these very complex countries.

These studies have the potential, in addition to collaborating for a more adequate knowledge of the countries with which we necessarily interact in the globalized world, to allow a deeper self-criticism of the Brazilian constitutional experience itself; and their gaps in law effectiveness.

There is no doubt that even the most renowned authors of Comparative Law (such as René David, Eric Agostin, Mario Losano, and Dário Vicente) stop in a more "classical" approach to the discipline without any deepening on the concrete configuration of the subject of, we can say, the state of effectiveness of fundamental rights in these constitutional orders. The research here reported acts precisely there, regarding the specific theme of women's rights and the situation of women and seeks to respond to the purposes of the current critical debates in Comparative Law, notably regarding the need for a dialogical and diatopical comparison, centered on the concreteness of legal experiences rather than normative abstraction. The work, as will be seen, is not confined to European literature, searching the research on the subject made by scholars of the countries themselves. Nevertheless, in the face of the difficulties arising from linguistic barriers, and the challenging diversity of the analyzed matrix, the research is anchored in the English-language productions, which can cause 
some analysis deficits, especially in the case of Russia and China (although there was a lot of production on the subject in both countries).

Rather than describing the nomological discourse on women's rights and women's protection policies in BRICS, this research sought to denounce the state of ineffectiveness of these rights and policies, despite the existing efforts to confront it.

\section{The situation of gender inequality and discrimination against women in Russia}

On the eve of 1918, a flourishing feminist movement already existed in Russia, and there is a considerable literature about the achievements on the liberation of women, such as education. ${ }^{1}$ However, the contribution of the Russian Revolution to the cause of women in the country is ambiguous. On the one hand, it is acclaimed for culminating in the first state to officially declare the total liberation of women among its objectives. ${ }^{2}$ On the other hand, the starting point of a government marked controversial "women's issue" and discriminatory and submissive social practices, ignored and reproduced by state authorities themselves, explain much of the problematic inheritance currently faced in post-Soviet Russia. To this immediate inheritance is added another oppressive inheritance of woman, more distant, linked to the patriarchalism of Orthodox culture.

Immediately, the rise of the Union of Soviet Socialist Republics meant a reorientation of actions aimed at extirpation of the inequalities between men and women in Russian society. In its first phase (1917-1930), the official discourse on the so-called "women's issue" was based on the understanding that the patriarchal structures of Russian society were derived from their class organization, so that with the restructuring of classes, the gender inequality would disappear.

Several laws were passed by the Bolsheviks in this regard (concerned, above all, to supposed the setback of women and its threat to the development of communism), on issues such as divorce, marriage, property, inheritance, and even abortion. In the same sense, many state provisions concerning childcare and domestic labor assistance were passed, aiming at the emancipation of women, seeking "communization" of these responsibilities. However, as Attwood points out, ${ }^{3}$ most of the individuals involved in such state services were themselves women, which, in part and obviously, contributed to the continuing understanding that it was up to women to take care of children and home.

With Stalin's coming to power in 1930, the "women's issue" was suddenly stated closed. ${ }^{4}$ Later on, as a result of World War II and the drastic decline of male population,

\footnotetext{
${ }^{1}$ Cf. Natalia Roudakova and Deborah S. Ballard-Reisch, "Feminity and the Double Burden: Dialogues on the Socialization of Russian Daughters into Womanhood," The Antrhopology of East Europe Review v. 17, No. 1 (1999); Diana Post, “Women's Rights in Russia: Training Non-Lawyers to Represent Victims of Domestic Violence", Yale Human Rights and Development Journal v. 4, No. 1 (2001); Natalia Pushkareva, Women in Russian History: From the Tenth to the Twentieth Century (New York: M. E. Sharpe, 1997).

${ }^{2}$ For a worthy review of the literature on the day-to-day life of women under the socialist regime, $c f$. Barbara Alpern Engel, "Women in Russia and the Soviet Union”, Signs v. 12, No. 4 (1987): 781-796.

${ }^{3}$ Lynne Attwood, The new Soviet man and woman: sex role socialization in the USRR (Bloomington: Indiana University Press, 1990).

${ }^{4}$ Mary Buckley, Women and Ideology in the Soviet Union (Hemel Hempstead: Harker Wheatsheaf, 1989). The author refers to the announcement made by Stalin regarding the end of the question of women in the year 1937: "The Soviet System has ended with exploitation, the lack of rights and slavery of women. The woman of the Union Socialist Soviet Republics is a new woman, an active participant at State administration and economic and cultural life management."
} 
women in Russia were forced to take over the industry void, generating what scholars have termed the "double burden" of Russian women, which is present until today. ${ }^{5}$

Forthwith, especially for demographic reasons, many reforms were implemented, repealing many of the rights guaranteed to women during the revolutionary period, with the criminalization of abortions, and the enforcement of a new family law in 1944, in order to increase birth rate, establishing a true cult of motherhood (women with more than five children received medals, and those who passed ten were awarded the status of "Mother Heroine", receiving a respective certificate of the government). Notwithstanding the clear contrast of the values reinforced by these measures to the revolutionary ideology, the absence of spaces for discussion and contestation during Stalinism left women with few options but to "thank" Stalin for their "emancipation."

The studies on this point indicate that from Khrushchev to Gorbachev, the "women's issue" in Russia would gradually become more prominent, while at the same time authorities would seek to erase the traces of Stalinist ideology and reform the legal status of women, aiming at a reduction of the gap between the equality formally declared in legal texts and by the official rhetoric (ravnopravie) and the factual inequality (ravenstvo) of woman. ${ }^{7}$ However, the strategies aimed at both will be based on an increasing gender essentialism. Vikki Turbine writes about how this "essentialism" was inherited from the Soviet period:

Over the post-Soviet period, many scholars have noted a resurgence in gender essentialism in Russia that has been particularly successful in framing public understandings of gender politics. The success of models of gender relations between men and women that extol the "natural" differences between men and women and their roles in society has in large part been ascribed to the persisting negative legacies of gender inequality from the Soviet period. While the Soviet model of gender equality gave women opportunities to participate in public fora that they were formerly excluded from (e.g. education, paid employment, and public offices), for many women, Soviet "equality" was experienced as a double or triple burden of care work, paid employment, and civic duties. This is because the prevailing model did notbing to address underlying structural inequalities based on gender nor dismantle patriarchal social systems.

Nevertheless, the demise of the Soviet Union and the liberalization of the economy and of the State did not bring significant change for women. If issues such as domestic violence, subordination and discrimination could now be publicly discussed, the values supported by the post-socialist Russian society (characterized as traditionalist and patriarchal) ${ }^{9}$ helped the official discourse to neutralize such discussions, avoiding the adoption of public policies specifically directed to combat situations such as gender discrimination in the labour market or the implementation of the fight against domestic violence, for example. Much is said about the "privatization" of women's rights, only intensifying the "double burden" that they have sustained in Russia since the mid1930s, and their "paradoxical" situation: demographic and economic important, but

\footnotetext{
${ }^{5}$ Roudakova and Ballard-Reisch, "Feminity and the Double Burden".

${ }^{6}$ Vikki Turbine, Women's perceptions of human rights and rights-based approaches in everyday life: a case study from provincial Russia. (PhD Thesis, Department of Central \& East European Studies, University of Glasgow, 2007).

${ }^{7}$ Turbine, Women's perceptions of human rights.

${ }^{8}$ Vikki Turbine, "Women's human rights in Russia: outmoded battlegrounds, or new sites of contentious politics?," East European Politics v. 31, No. 3, (2015): p. 328 [Own translation].

${ }^{9}$ Tatiana Fedorova, Tatiana Savitskaya and Anna Yakovleva, Gender Equality and Culture (Russian Federation), retrieved from: http://www.unesco.org/new/fileadmin/MULTIMEDIA/HQ/CLT/images/ Informkultura_Russian_State_Library_Gender_Equality_and_.pdf.
} 
politically silenced, a silence that is noticed by women's very low presence in government positions, at the highest level s in public management, or in the direction of private companies.

As a result, in 2017, the Russian Federation ranked $54^{\text {th }}$ in the ranking of the United Nations Gender Inequality Index. Only 14.5\% of parliamentary seats were held by women, although $95.8 \%$ of women had a high school or higher education level, compared to $95.3 \%$ of men, and $56.6 \%$ of the female workforce was in the labour market, against $71.8 \%$ of men, for example. ${ }^{10}$

Thus, despite Article 19 (3) of the 1993 Constitution, which reads: "Man and woman shall enjoy equal rights and freedoms and have equal possibilities to exercise them", 11 a formulation that is repeated in several other legal instruments, this fundamental right has encountered difficulties at densification.

The Labour Code of the Russian Federation of December 31, 2001, appears ambiguously in this context. Article 3 (2) prohibits any form of discrimination, including by sex. However, the following line establishes that "distinctions, exceptions, preferences, as well as limitation of employees' rights which are determined by the requirements inherent in a specific kind of work as set by federal laws or caused by special attention of the state to the persons requiring increased social and legal protection, shall not be deemed discrimination." 12 This is often used (and distorted, in our view) as a basis for discriminatory practices against women, such as the possibility in Russia of certain jobs being exclusive for men, if it is considered that their nature justifies the exclusion, such as the conditions of physical and health requirements of a particular profession. Thus, Article 253 establishes restrictions on the employment of women. Women cannot be employed in activities considered difficult, dangerous or unhealthy in Russia.

The definition of maximum weight to be lifted by women, as well as the list of activities considered difficult, dangerous and unhealthy, are established by the initiative of the Government of the Russian Federation, through its self-defined procedure, provided that the Trilateral Commission (State and Workers) on the Regulation of Social and Labour Relations is consulted. To this day, those definitions are in force by way of Government Resolution No. 162 of February $25^{\text {th }}$, 2000. In total, there are 465 activities and 38 branches of industry considered as inadequate for women. What is even more striking is that most of these restrictions are justified especially by their reproductive capacities..$^{13}$ The understanding that women are essentially mothers and

\footnotetext{
${ }^{10}$ United Nations (UN), Gender Inequality Index, 2017, retrieved from: http://hdr.undp.org/en/composite/GII.

${ }^{11}$ Russian Federation, Russian Federation's Constitution of 1993 with Amendments through 2008, December, $12^{\text {th }}, 1993$, retrieved from: https:// www.constituteproject.org/constitution/Russia_2008.pdf, [Own translation].

${ }^{12}$ Russian Federation, Labor Code of the Russian Federation. December, 31 ${ }^{\text {st }}$, 2001, retrieved from: http:/ / www.ilo.org/dyn/natlex/docs/WEBTEXT/60535/ 65252/E01RUS01.htm, [Own translation].

${ }^{13}$ Committee on the Elimination of Discrimination against Women. Communication No. 60/2013. Geneva, March 21, 2016. The Russian Federation is a party to the Convention on the Elimination of All Forms of Discrimination against Women of the United Nations. The document in question came in response to the Committee responsible for observing compliance with and implementation of the convention after communication by Svetlana Medvedeva. Medvedeva graduated in 2005 from the College of Navigation in her region, qualifying as a navigational officer. In 2012, Medvedeva presented herself to the position of helmswoman at a private fluvial passenger transport company. Initially approved, it was subsequently rejected on the basis of Government Resolution No. 162 of February 25, 2000. After losing also in the Russian Justice, Medvedeva lodged a complaint with the
} 
that they are exclusively responsible for caring for their children is manifested at other occasions in the Labour Code, being examples of this restriction on night work and overtime. Women with children under 3 years of age cannot work at night (Article 96 (5)) and are advised not to work on holidays and beyond normal working time (Article 9 (3), Article 113 (5)). It can be argued that what is presented as being a protection for women is actually a reduction of their job opportunities.

However, these restrictions do not appear to be internally challenged as discriminating against women. What is seen, both in public opinion and in Russian legal conscience, is a gender neutralization of discriminatory practices, as if, in Russia, there were only labour discrimination because of other factors, not because of sex. ${ }^{14}$

These facts help to explain, at least in part, the current enactment state of a bill entitled "State Guarantees of Equal Rights and Opportunities for Men and Women", which has been debated legislatively since 2005. This piece of legislation is specifically aimed at combating discriminatory practices based on gender differences. There is, however, no success of its approval, in over ten years since its original proposal, despite the serious indicators of its importance and necessity, such as the constant and outrageous wage gap, which from the beginning of the 1990s until 2003 remained the same. Women earn, on average, $64 \%$ of what men earn. ${ }^{15}$

In a similar situation, it is the draft law on domestic violence, which has been in progress since 1995. If a lengthy legislative process does not constitute the reproduction of a discriminatory understanding between men and women, the context in which such delay occurs is at least alarming. After all, according to estimates by the Russian Interior Ministry, around 600,000 women experience abuse at home or by intimate partners, with 40 women dying daily as a result of this violence, ${ }^{16}$ reaching 14,000 deaths a year. Comparatively, Human Rights Watch, following an independent research, estimates that 36,000 women and 26,000 children are victims of domestic violence every day. ${ }^{17}$ However, studies say police officers systematically refuse to receive reports of domestic violence cases and, in cases of rape, often blaming the victims, overriding any public commotion. $^{18}$

More recently, in 2016 the Russian parliament had adopted amendments to the country's criminal code criminalizing domestic violence. These measures were intensely

Committee, which gave her cause and made several recommendations to Russia to correct these situations of discrimination labor market. Up to the present moment there is no news or evidence that the Russian State will follow the Committee's recommendations.

${ }^{14}$ Based on a series of interviews with a broad spectrum of women, Vikki Turbine and Kathleen Riach highlight the current trend in the common discourse of Russian women in assimilating the gender neutralization diffused by the official discourse, advanced the interpretation that any victim of discrimination may, if you try hard enough, overcome such difficulties. Further, the authors offer a nuanced interpretation of the contradictory forces underlying such phenomena and the resulting tensions, suggesting that, despite the perpetuation of inequality caused by this type of discourse, their use is most likely due to women's Russia to identify themselves as helpless victims, in accordance with the cultural norms prevailing in Russia. Cf. Vikki Turbine and Kathleen Riach, "The Right to Choose or Choosing What's Right? Women's Conceptualizations of Work and Life Choices in Comteporary Russia," Gender, Work and Organization, v. 19, No. 2, (2002).

${ }^{15}$ Natalia Rimashevskaya, "Gender relationships and gender policy in contemporary conditions", Intellectual Economics, v. 7, No. 1, (2013): 54-62.

${ }^{16}$ Turbine, "Women's human rights in Russia", 326-341.

${ }^{17}$ Cf. Human Rights Watch, Russia: Bill to decriminalize domestic violence, Jan. 23, 2017, retrieved from: https://www.hrw.org/news/2017/01/23/russia-bill-decriminalize-domestic-violence.

${ }^{18}$ Diana Post, "Women's Rights in Russia: Training Non-Lawyers to Represent Victims of Domestic Violence," Yale Human Rights and Development Journal, v. 4, No. 1 (2001). 
criticized by conservative politicians and the orthodox leadership. Therefore, in 2017, following the proposal of ultra-conservative lawmaker Yelena Mizulina, the government has reversed, through an almost unanimous vote on its yesteryear legal development, decriminalizing once again domestic violence, which returned to be legally framed as of private, not public, interest, and, consequently, a matter of administrative and not criminal law. ${ }^{19}$

Trafficking of women was recognized at the beginning of 2000 as a national security problem, with the Russian State signing various international treaties, pacts, and conventions aimed at combating human trafficking, with the subsequent promotion of the necessary amendments in the current Criminal Code, introducing two provisions (Articles 127.1 and 127.2, respectively) criminalizing directly both human trafficking and the use of slave labour. The numbers are alarming. It is estimated that between 30,000 and 60,000 women and children are withdrawn annually from the country, especially for prostitution. ${ }^{20}$ Regardless of official efforts (between 2005 and 2011, around 250 criminal cases were brought before the courts related to the aforementioned Articles 127.1 and 127.2), ${ }^{21}$ the problem seems far from being circumvented. Public opinion, on the other hand, according to research by Mary Buckley, ${ }^{22}$ while condemning human trafficking, links its solution to a strengthening of family values, with the interviewed citizens not expressing interest to be actively involved in solving it.

\section{The situation of gender inequality and discrimination against women in India}

In India, its Constitution guarantees women the right to equality (Article 14), which is developed in the Constitution itself in the most diverse provisions (Articles 15, $16,19,21,23,38,39,42,44,243 \mathrm{D}$ and $243 \mathrm{~T}){ }^{23}$ with a strong normative densification, at least if it is considered the quantity of legal norms. After all, there are innumerable Indian laws and policies concerning women, such as the Dowry Prohibition Act (1961), a Hindu Marriage Act (1955), a Hindu Successions Act (1956), the Protection of Women from Domestic Violence Act (2005), the Sexual Harassment of Women at Work Place (Prevention, Prohibition \& Redressal) Act (2013), the Indian Divorce Act (1969), the Equal Remuneration Act (1976), the Muslim women (protection of rights on divorce) Act (1986), the specific classification of crimes against women (Sections 376, 363-373, 302/304-B, 498 A, 354 and 509 of the Indian Penal Code), and the "National policy for the empowerment of women" (2001), among others.

Nonetheless, as Robert D. Baird has convincingly argued from a legal-historical perspective, the constitutional text in force for more than 60 years, which affirms a modern and progressive system of values, especially with regard to women, is in clear

\footnotetext{
${ }^{19}$ Nerses Isajanyan, "Russian Federation: Decriminalization of Domestic Violence. The Law Library of Congress," Global Legal Research Center (jun. 2017).

${ }^{20}$ Irina Ivakhnyuk and Vladimir Iontsev, Human Trafficking: Russia. [Explanatoy note 13/55 - Consortium for Applied Research on International Migration] (San Domenico di Fiesole, Italy: Migration Policy Center, 2013).

${ }^{21}$ Ivakhnyuk and Iontsev, Human Trafficking.

${ }^{22}$ Mary Buckley, "Public Opinon in Russia on the Politics of Human Trafficking," Europe-Asia Studies, v. 61, No. 2, (2009): 213-248.

${ }^{23}$ For a detailed analysis, including jurisprudence, of all constitutional provisions related to women,, cf. Anju Singh, "The Role of Law in Empowering Women in India" (PhD Thesis, University of Lucknow, Lucknow, 2013).
} 
conflict with the still strong and present traditional normative comprehension toward women $^{24}$ (despite its undoubted pluralism). ${ }^{25}$ Thus, as Michael Dusche put it, roughly, most Hindus, Muslims, Christians, Sikhs, urban, rural, or tribal, tend to agree that woman's place is at home, not in public, and if she wants to venture out, this should happen preferentially by day, dressed in modest clothes, and ideally accompanied by other family members whom can act as her protectors. ${ }^{26}$

In the words of Sudhir Kakar, Indian society traditionally defines the personality of an individual (that is, his/her dignity as a person) from his/her relationships, not his/ her individuality. Thus, as a mother, daughter, sister or wife, a woman is undoubtedly worthy of respect. However, outside of these categories and contexts, women either are a "female", a "bhog ki cheez" (an object of pleasure) or, when displaced from their obligations, in need of punishment by the form of sexual violence. ${ }^{27}$ This conflict between relationship and individuality, or, at Michael Dusche's own suggestion, between hierarchy and equity is at the heart of the situation of women in India, building and influencing the cultural horizon of reproduction and realization of law in this regard.

In the sensitive words of Anju Singh, ${ }^{28}$ women in India strive for their rights since being born, which are constantly emotionally, familiarly, religiously and economically silenced. This is illustrated, for example, by the complex practice of the dowry (basically, the carrying out of economic and financial transactions between the family of the bride and the family of the groom, consisting of the dowry of goods and money from the first to the second), ${ }^{29}$ which was legally banned but still practiced (in 2010 there were 5,182 cases of the practice, criminalized since 1961). ${ }^{30}$ Another confirmation of this state of things is the stereotyped view of women in Indian society, which causes them to be socially deprived even before birth. It is quite a common understanding to signal as a misfortune a couple's expectancy of a daughter.

In the national census conducted in 2011, it was found that the ratio of sex in India is 1000 men to 943 women. The ratio of child sex, in turn, is 1000 to $919 .{ }^{31}$ This is a consequence of the negative values (especially financial) attributed to the birth of a girl. While it is believed that a growing boy will contribute to the family's livelihood, and when married, will receive the respective dowry, a girl will be another person to support, with the family having to spend resources itself to pay her dowry when she gets married. So, the country faces a serious problem of gender-based infanticide and

\footnotetext{
${ }^{24}$ Cf. Bhimrao Ramji Ambedkar, The rise and fall of Hindu woman (Jalandar: Bheem Patrika Publications, 1980).

${ }^{25}$ Cf. Maarten Bavinck et al., "From indifference to mutual support - A Comparative Analysis of Legal Pluralism in the Governing of South Asian Fisheries," European Journal of Development Research, v. 25, No. 4, (2011): 621-640.

${ }^{26}$ Michael Dusche, "Women's Rights in India: Hierarchical Ethics versus Egalitarian Morality," South Asia Chronicle, v. 4, (2014): 228-253.

${ }^{27}$ Sudhir Kakar, "Vergewaltigungen in Indien: Entwurzelte Männer sehen Frauen als Freiwild," Spiegel Online, May 31, 2013, http://www.spiegel.de/kultur/gesellschaft/der-indische-psychoanalytikersudhir-kakar-ueberverg ewaltigung-a-901769.htm.

${ }^{28}$ Singh, "The Role of Law in Empowering".

${ }^{29}$ For a discussion of the origins of practice and the construction of its legal conceptualization, $c f$. Nidhi Gupta, "Women's Human Rights and the Practice of Dowry in India," The Journal of Legal Pluralism and Unofficial Law, v. 35, No. 48, (2003): 85-123.

${ }^{30}$ Rasida Begum, "Violation of Women Rights in India," International Journal of Humanities \& Social Science Studies, v. 1, No. 3, (2014): 216-224.

${ }^{31}$ Republic of India, 2011 Census of India, May 20, 2013, retrieved from: http://censusindia.gov.in/.
} 
fetocides ${ }^{32}$ : "It's better to spend 500 rubles now on the test than 50,000 in a dowry for the daughter", as the common saying has it. Despite the financial incentives offered by the Indian government to perform childbirth in public hospitals and the birth of girls, there has been no major transformation of this situation in the last two decades. ${ }^{33}$

However, the problem of dowries is not restricted to birth. According to Eleonora Corsini's surveys ${ }^{34}$ when it is considered insufficient or unsatisfactory, it is common for the husband to abuse or violate his wife continuously, until she is killed (usually burnt), ${ }^{35}$ or commits suicide. The practice is typified by the Indian Penal Code in its Article 304 (B). ${ }^{36}$ Despite this, in 2011, the National Criminal Records Service of India recorded 8,618 female deaths related to dowries. The Asian Women's Council on Human Rights estimates that 25,000 women between the ages of 15 and 24 are killed annually for the same reason. ${ }^{37}$

The numbers are also shocking regarding rape cases. According to the National Criminal Records Service, 24,206 cases were recorded in 2011. More frightening is the way in which society and even the Indian judiciary interpret such events.

In January 1996, Michael Dusche a sixteen-year-old girl from Suryanelli, Kerala, fled with her boyfriend and later she was abandoned by him and fell into the hands of a couple who raped and confined her and forced her to prostitute for forty other men in a period of forty days. In 2000, the local court sentenced thirty-six of the forty men and the woman. The decision was appealed and in 2005, the Kerala High Court acquitted thirty-five of the defendants, arguing that the girl had consented to the sexual acts. The judges decided in this way because of the "character" of the victim, who had practiced

32 According to Anantanad Ramechan, a prominent theologian of Hinduism, of the 13,400 abortions performed by a specialized clinic in New Delhi between 1992 and 1993, 13,338 were of female fetuses. Another study, cited by the author, shows that of the 8,000 aborted fetuses in the state of Maharashtra, 7,999 were female. For the author, such practice is the main cause of the current ratio of sex in India. Anantanad Ramechan, "A Hindu Perspective" in What Men Owe to Women: Men's Voices from World Religions. Daniel C. Maguire; John C. Raines, (Albany: State University of New York Press, 2001).

${ }^{33}$ Emma Livne, Violence Against Women in India: Origins, Perpetuation and Reform (2015), http:/ /www.cmu. edu/hss/globalstudies/images/livne-gs-capstone-paper.pdf. O link encontra-se inativo, solicitor aos autores um link de acesso ao texto

${ }^{34}$ For example, Eleonora Corsini, tells about the Kishna Kumary case, in which Mr. Kumary harassed his wife because a television and an air conditioner were not included in the dowry. Shortly afterwards, his wife appeared dead in the kitchen, with her husband and brother-in-law arguing that it was an accident, despite the death examination concluding that death had been caused by suffocation. In the first instance, the husband was acquitted for lack of evidence. Only when the case came to the Supreme Court that he was brought to trial, and then convicted, of. Eleonora Corsini, Law Alone Cannot: Women's Empowerment in India (2012), http:/ / www.luc.edu/media/lucedu/prolaw/documents/ pdfs/3studentjournalcorsini1.pdf.

${ }^{35}$ Stoves fueled by kerosene are very common in India, such as the habit of keeping fuel in reserve. Because fire not only eliminates the victim as virtually all evidence of death, there is a predilection for such a course of action in domestic crimes related to dowries. Thus, the following is provided in article 304 (B) of the Indian Penal Code: "Where the death of a woman is caused by any burns or bodily injury or occurs otherwise than under normal circumstances within seven years of her marriage and it is shown that soon before her death she was subjected to cruelty or harassment by her husband or any relative of her husband for, or in connection with, any demand for dowry, such death shall be called "dowry death", and such husband or relative shall be deemed to have caused her death." (Republic of India, The Indian Penal Code, October 6 $\left.{ }^{\text {th }}, 1860\right)$ [Own translation].

${ }^{36}$ Nidhi Gupta argues that government policies, including criminalization, aimed at combating the practice of dowry are partial and simplistic, failing to opt for the imposition of Westernized patterns of individuality and human rights in the face of religiously and economically rooted customs and, consequently, such issues. (cf. GUPTA, "Women's Human Rights").

${ }^{37}$ Livne, Violence Against Women in India. 
sexual acts with her boyfriend before the wedding, what they understood as a deviation from that which was expected from an innocent girl of her age. In other words, she would be blamed for other men have taken advantage of her "promiscuity." In 2013, the Supreme Court of India would declare such a judgment as shocking, determining its review. On April 4, 2014, a new bench of the High Court of Kerala sentenced one of the defendants to life imprisonment, while another 22 were sentenced to long years of imprisonment. Seven were acquitted, and five died during the trial. Still, the defense alleged that the victim would have relapsed and may have escaped during the time she was captive. ${ }^{38}$

Following the collective rape of a 23-year-old student in Delhi on December 16, 2012 , international public opinion turned itself completely to the issue in India. The result of international pressure was the establishment of a committee by the Supreme Court of India, led by Justice J. S. Verma. On January 23, 2013, the committee published an extensive report suggesting a number of reforms in the current legislation, ${ }^{39}$ among them, for example, the criminalization of marital rape (a recommendation hitherto not followed). As the initial stance of the Kerala High Court bench illustrates, the traditionalist view about the place of women in India is not restricted to the deepest and marginal regions of society, it also applies to a part of the Indian state elite.

Nonetheless, gaining publicity for laws is a serious obstacle in the fight against gender inequality in India. For example, with regards to family law, ${ }^{40}$ Upendra Baxi, commenting on a study by B. B. Chatterjee on access to legal information in four villages in Banaras district, points out that the interviewees had no knowledge of the minimum legal age for marriage, ${ }^{41}$ or that the practice of dowry had been banned. Little did they know about divorce regulations. As for the Law of Hindu Succession, only 12 out of the 200 respondents reported having any knowledge about it, with the only exception being the provision related to the right of inheritance that women obtained. According to Baxi, while $68 \%$ of the respondents from the higher castes were strongly opposed to the measure, $71 \%$ of the others saw it favorably in the other castes. ${ }^{42}$

Women in India also face obstacles to education and employment, even though there are specific laws and public policies for both related problems, as well as a considerable number of judicial decisions. ${ }^{43}$ Thus, the literacy rate is $65.50 \%$ among women, compared to $82.10 \%$ among men $^{44}$ (with a dropout rate $10 \%$ higher among

\footnotetext{
${ }^{38}$ Dusche, "Women's Rights in India".

${ }^{39}$ J. S. Verma et al., Report of the Committee on Amendments to Criminal Law. (January 23 $\left.{ }^{\text {rd }}, 2013\right)$, http:/ / apneaap.org/wp-content/uploads/2012/10/Justice-Verma-Committee-Report.pdf.

${ }^{40}$ Although many of the controversies in this area are consequences of the present and inescapable structure of the Indian legal system, in which it is allowed the validity, under the constitutional aegis, of several normative religious orders, based on the principle of the personality. Thus, there is a constant political game, with intense pressure from the respective religious communities to keep a series of issues governed by their own personal norms, such as inheritance, marriage, divorce, property. $C f$. Brenda Cossman and Ratna Kapur, "Women and Poverty in India: Law and Social Change," Canadian Journal of Women and the Law, v. 6 (1993); Martha C. Nussbaum, "India: Implementing Sex Equality Through Law," Chicago Journal of International Law, v. 2, No. 1 (2001): 35-58.

${ }^{41}$ Cf. Kounteya Sinha, "Nealry 50\% fall in brides married below 18," The Times of India, Feb, $10^{\text {th }}$, 2012, http://timesofindia.indiatimes.com/india/Nearly-50-fall-in-brides-married-below-18/articleshow/11829410.cms.

${ }^{42}$ Upendra Baxi, Toward a Sociology of Indian Law (Nova Delhi: Satvahan Publications, 1986).

${ }^{43}$ For an analysis of the jurisprudence of the Supreme Court of India on gender discrimination in the labor market and the right to education, $c f$. Singh, "The Role of Law in Empowering".

${ }^{44}$ Republic of India, 2011 Census of India, May 20, 2013, retrieved from: http://censusindia.gov.in/.
} 
women than among men); $73.78 \%$ of the rural labour force is composed of men, compared to $26.22 \%$ of women. These numbers, which should be better in urban contexts, are not: the ratio of jobs in urban areas is $84.76 \%$ to $15.24 \%$, with women earning between 20 and $60 \%$ less than a man's average wage. The result is a vicious circle in which women, because they have comparatively less professional training and schooling than men, cannot compete for jobs in the labour market, even less in urban centers. Consequently, $94 \%$ of the female labour force is made up of self-employed workers, mostly located in the countryside. ${ }^{45}$

Thus, there is a serious problem of effectiveness, which is constituted in an extremely complex way. From the lack of publicity of legislative progress, to the tense relations between state law and the series of normative orders of a traditional character, it can be characterized as a case of "low constitutionality" (low permeability to constitutional language), encompassing also political and state actors culturally immersed in the still present patriarchal hierarchy of Indian society and its comprehension of women. It is necessary to emphasize the context in which this verticalization happens between men and women. Despite the clear constitutional provisions about it, part of the social stigma of castes and untouchable tribes remains and makes the situation of women belonging to these castes even more difficult. ${ }^{46}$

It is possible to identify traces of moral stereotypes required of Indian women in the legislation itself, in various distinctions built in criminal law, family law, and even inheritance law. In the latter case, for example, despite the fact that women today has the right to inheritance, their share comes from the father's patrimony (and he may, if he wishes, exclude them by testament), and not from the family's one as a whole, while men receive a portion of the "ancestral property," together with the share corresponding to the father's estate. ${ }^{47}$

It is partly possible to attribute such a state of things to women's lack of political representation. India ranks 130th in the ranking of the Gender Inequality Index built by the United Nations. While $63.5 \%$ of the male population has a high school education or higher, only $39,0 \%$ of women have a similar level of education (between 2010 and 2017). 78.8\% of the male labour force is employed, as against $27.2 \%$ of the female labour force (in 2017). Finally, women occupy only $11.6 \%$ of parliamentary seats. ${ }^{48}$

Such a democratic deficit (considering that almost half of its immense population, of $1,326,801,576$ people in 2016 , is made up of women) has already been identified as a problem by a portion of Indian society. Since 1996, attempts have been made to pass a constitutional amendment reserving 33\% of the seats in the national parliament (Lok Sabha) and in state assemblies for women, the latter having occurred in the year 2010. The political resistance to both, however, is surprising. From feminist movement representatives to excluded caste politicians, as well as those of a clearly conservative alignment (fearful that such reserves would threaten their culturally established practices), the project is criticized from its very foundations as an affirmative action, even its possible consequences and mechanisms

\footnotetext{
${ }^{45}$ Cossman and Kapur, "Women and Poverty in India".

${ }^{46}$ Cf. Justin. P José, "Identity and Social Exclusion of Dalit Women: A psychosocial perspective,"

Contemporary Voice of Dalit, v. 8, No. 2 (2016): 136-162.

${ }^{47}$ Cossman and Kapur, "Women and Poverty in India".

${ }^{48}$ United Nations (UN), Gender Inequality Index, 2014, retrieved from: http://hdr.undp.org/en/ composite/GII.
} 
proposed for the selection of future representatives. ${ }^{49}$

\section{The situation of gender inequality and discrimination against women in China}

Whatever the position on the legacy of communism in China, it was in consequence of it, and consequently, in the last 50 years, that the most dramatic changes have occurred in relation to the lives of women in the country. It is with such words that Anne M. Han suggests that the year 1949 was a watershed for the situation of women in China. ${ }^{50}$

In this sense, it can be said that even with the beginning of the process of modernization at the end of the dynastic period, with the advent of the Revolution, only in 1921, with the creation of the Chinese Communist Party and its actions, the woman question started to have relevance in the public space. For example, as early as 1911, the Republican government that followed the end of the Qing Dynasty had initially denied women the right to vote. ${ }^{51}$ And so, in 1949, with the rise of Mao Zedong and the implementation of Marxist reforms, a series of measures were introduced, including some at constitutional level, as in the constitutional texts of $1949^{52}$ and $1954^{53}$, but at the infra-constitutional level as well, notably the much studied Marriage Act of $1950^{54}$ - aiming to eradicate any type of gender discrimination hitherto legalized.

From second-class citizens, at best, to the "half sky" 55 keepers, supported by the official Maoist ideology that saw women as examples of heroines, warriors, and

\footnotetext{
${ }^{49}$ Vicky Randall, “Legislative gender quotas and Indian Exceptionalism: The Travails of the Women's Reservation Bill," Comparative Politics, v. 39, No. 1, (2006): 63-82.

${ }^{50}$ Anne M. Han, "Holding-up more than half the sky: marketization and the status of women in China," International Journal of Contemporary Legal Issues No. 11 (2001): 791-810.

${ }^{51}$ Charlotte L. Behan, "In the Public Eye: Women in Early Twentieth-Century China", in Women in China: Current Directions in Historical Scholarship, eds. Richard W. Guisso; Stanley Johannessen (Youngstown: Philo Press, 1981).

${ }^{52}$ By Article 6 of its famous Common Program, the Communist Party of China declared in 1949:

"The People's Republic of China shall abolish the feudal system which holds women in bondage. Women shall enjoy equal rights with men in political, economic, cultural; educational and social life. Freedom of marriage for men and women shall be put into effect" [Own translation]. (Communist Party of China, The Common Program of the Chinese People's Political Consultative Conference, Sept, 29 ${ }^{\text {th }}$, 1949, retrieved from: http://e-chaupak.net/database/chicon/1949/1949e.pdf).

53 Article 96 of the Chinese Constitution of 1954: "Women in the People's Republic of China enjoy equal rights with men in all spheres of political, economic, cultural, social and domestic life. The state protects marriage, the family, and the mother and child".

${ }^{54}$ According to Gail Hershatter: "The 1950 Marriage Law of the PRC abolished 'feudal marriage" and 'marriage by purchase' and established freedom of choice as a fundamental principle (Meijer 1971; Davin 1976; Ono 1989; Croll 1981; K. Johnson 1983; Stacey 1983; Ocko 1991). The law also asserted the rights of adults to divorce at will" Gail Hershatter, Women in China's Long Twentieth Century (California: University of California Press, 2007), 16. The radical nature of the proposed changes, the author continues, can be seen in part in the deep resistances it has aroused. For example, having bought a wife for their son and a daughter-in-law for themselves at considerable prices, many parents, especially in rural areas, felt outraged at the prospect of losing their investment because of a divorce. Thus, attempts by the government to put the law into effect were nagging.

${ }^{55} \mathrm{It}$ is attributed to Mao Tse-Tung the evocative proclamation that women hold up half the sky. In fact, from the interviews carried out by sociologist Jiping Zuo with women who lived and worked during the period, it is possible to perceive a generalized sense of participation, belonging, achievement and pride, due, for example, to the incentives to take jobs away from home. Cf. Jiping Zuo, Work and Family in Urban China: Women's Changing Experience since Mao (New York: Palgrave Macmillan, 2016).
} 
comrades, women in China, especially in urban centers and in the state structure, would increasingly take up space in Chinese society. However, despite the chaos and terror of the Cultural Revolution, many scholars ${ }^{56}$ find setbacks in the situation of women in China after 1978, with the series of reforms initially introduced under the leadership of Deng Xiaoping.

Although the Constitution of 1982 remains in the established tradition, it formally declares the equality between men and women in all spheres of life, whether political, economic, cultural, social or in family Article 48 (1), including the protection of women's rights and interests, as well as equal pay and access to public service Article 48 (2). The infra-constitutional densification at the legislative and administrative levels, and the effectiveness of these fundamental rights have been at best ambivalent.

Thus, in the ranking of the Gender Inequality Index constructed by the United Nations Development Program, ${ }^{57}$ in 2017 , China was $86^{\text {th }}$. Only $24.2 \%$ of parliamentary seats were occupied by women; $74.0 \%$ of women in China had higher education, compared to $82.0 \%$ of men between 2010 and $2017 ; 61.5 \%$ of the female labour force is employed, compared to $76.1 \%$ of the male workforce in 2017. Despite its comparatively positive ratings, the situation of women in China is still very uneven and the reasons for this inequality deserve to be analyzed.

These statistics reflect three of the main problems facing women in China today: the stereotyped view of women to inform legal, legislative and administrative production (especially in the field of labour law) $;^{58}$ discriminatory practices in the labour market; and the consequent urban exodus, with many women in situations of "forced migration" or marginalization, when they see no alternative, but return to the interior, or resort to prostitution to meet their basic needs.

From the Reformation period onwards, as if to deny the Maoist doctrine of the past, officially denounced as naive and counterproductive, women would no longer be seen as identical to men, including in their labour skills. On the contrary, official discourse goes on to assert their fragility and a natural propensity to the motherhood and the domestic chores. These figures are regulated in a series of legally imposed requirements for employers to hire women, such as the construction of nurseries, the granting of maternity leave for a period of not less than 90 days, and several other measures aimed at the social security of children; ${ }^{59}$ in the prohibition of the employment of women in activities considered to be of "high intensity" and underground mining

\footnotetext{
${ }^{56}$ For a review of the existing literature, see Hershatter, Women in China's Long.

${ }^{57}$ United Nations, Gender Inequality Index, 2017, retrieved from: http://hdr.undp.org/en/composite/ GII.

${ }^{58}$ Sobre o direito trabalhista na China, em geral ver Solicitar ao autor que transcreva para o inglês Dan Wei, "Um olhar sobre relações laborais em mudança na China," Boletim da Faculdade de Direito, v. LXXXV, (2009): 261-277.

${ }^{59}$ The right to maternity leave and its minimum period are defined in Article 61 of the Labor Law of People's Republic of China of 1995. cf. People's Republic of China, Labour Law of the People's Republic of China, January 5 ${ }^{\text {th }}, 1994$, retrieved from: http://www.npc.gov.cn/englishnpc/Law/2007-12/12/ content_1383754.htm>; People's Republic of China, Law on the Protection of Women's Rights and Interests of the People's Republic of China, April 3 ${ }^{\text {rd }}$, 1992, retrieved from: https://www.justice.gov/sites/default/ files/eoir/legacy/2013/11/08/Protection\%20of\%20Women's\%20Rights.pdf. The existence of such regulations does not, however, imply their effectiveness. According to study led by Bohong Liu, Yongying Zhang and Yani Li to the International Labor Organization, until 2005, only 5\% of urban enterprises had nurseries and outpatient clinics, cf. Bohong Liu et al., Reconciling work and Family: Issues and policies in China. A Working Report to International Labour Organization (Geneva: International Labour Organization Office, 2008).
} 
activities, as well as their work in high altitude places, cold weather, or cold waters when menstruating; ${ }^{60}$ in the use of various indeterminate concepts concerning the permitting or not of certain labour activities for women, ${ }^{61}$ corroborated by a considerable period of discriminatory practices.

Therefore, although some of the legal measures may be seen as "humanizing"62 by international public opinion, in China, the market does not share such opinion nor is it subject to mechanisms capable of enforcing it accordingly. As a consequence, besides being deprecated due to their reduced competitiveness ${ }^{63}$ because of their obligations (understood as a result of protectionist paternalism by Ogletree and Silvade-Alwis), ${ }^{64}$ when employed (that is, in those branches and activities for which they can be), they hardly find legally adequate working environments. To add insult to injury, women face considerable impediments in accessing the legal machinery to get such working environments to conform with the law. ${ }^{65}$

Discrimination suffered on grounds of gender, in turn, fits into a larger context. According to Jiefeng Liu, ${ }^{66}$ combating discriminatory practices, both in labour and

${ }^{60}$ Prohibitions established by the articles 59 and 60 of the Labor Law of People's Republic of China; cf. People's Republic of China, Labour Law of the People's Republic of China, June $5^{\text {th }}$, 1994, retrieved from: http://www.npc.gov.cn/english npc/Law/2007-12/12/content_1383754.htm.

${ }^{61}$ For example, this was done through art. 23 of the Law on Protection of Women's Rights and Interests: "With exception of the special types of work or post unsuitable to women, no unit may, in employing staff and workers, refuse to employ women by reason of sex or raise the employment standards for women". (People's Republic of China, Law on the Protection of Women's Rights and Interests of the People's Republic of China, Apr. 3 ${ }^{\text {rd }}$, 1992, retrieved from: https://www.justice.gov/sites/default / files/eoir/ legacy/2013/11/08/Protection\%20 of\%20Women's\%20Rights.pdf. [Own translation]). According to Burnett: "The LPRIW makes it more difficult for women to get hired in China. Allowing employers to refuse to hire women for tasks that are "unsuitable for women" created an opening for employers to discriminate, arguably in violation of the Constitution" (Jamie Burnett, "Women's Employment Rights in China: Creating Harmony for Women in the Workplace," Indiana Journal of Global Legal Studies v. 17, No. 2 (2010): 305 [Free translation]).

${ }^{62}$ Ogletree e Silva-de-Alwis point out, however, that even such regulations have serious problems in their assumptions: "Further regulations have been promulgated to provide special on-the-job facilities for women, including health care rooms, anterooms for pregnant women, feeding rooms, nurseries, and kindergartens. The labor law also provides special consideration for pregnant or lactating women. These regulations, structured around a woman's reproductive cycle, limit the hours women may work and regulate the benefits a woman worker receives during menstruation, pregnancy, post-pregnancy, and menopause. In effect, these regulations promote the notion that a woman's primary responsibility is to give birth, care for young children, and attend to their reproductive capacities. These intrusive regulations are viewed as necessary for the welfare of the family's community. Concerns for family and community, however, are not apparent in legislation covering male employees. By focusing on biological differences in a way that excludes male workers from responsibility for neo-natal and postnatal visits and child care, Chinese labor law thrusts child bearing and child rearing responsibilities entirely upon women.". (Charles Ogletree and Rangita de Silva-de-Alwis. "When Gender Differences Become a Trap: The Impact of China's Labor Law on Women," Yale Journal of Law \& Feminism v. 14, No. 1, (2002): $77-$ 78 [Free translation].

${ }^{63}$ Anne M. Han refers to a survey conducted by the All China Federation of Trade Unions with 660 factories employing 15,000 workers in total, where only $5.3 \%$ of respondent employers were inclined to hire women to positions that were suitable for both sexes. The reason for this, continues the author, is primarily economic. Thus, it is estimated that the costs of pregnancy, labor and maternity leave are around 1,259 Yuan per worker. (Cf. Han, "Holding-up more than half the sky", 791-810).

${ }^{64}$ Cf. Ogletree; Silva-de-Alwis, "When Gender Differences".

${ }^{65}$ See infra.

${ }^{66}$ According to Anne M. Han, the discrepancies between men and women in the Chinese labor market start from education. So, even though compulsory basic education exists in China, schools are now charging ever higher fees for books and "extras." Consequently, especially in the countryside, 
other areas, such as education and public transportation - which is not motivated only by sex, as other factors, from height and appearance to ethnicity, have their influence - was not a relevant issue for the official Chinese discourse in the last fifteen years. ${ }^{67}$ Therefore, despite its constant and structural occurrence in China, between 2000 and 2011, only 92 cases involving discrimination were filed in court. ${ }^{68}$

Regarding women and discrimination in the labour market, the negligible number of legal disputes is explained, in the opinion of Jiefeng Liu, on the grounds of the applicability and procedural scope of the relevant regulations. In other words, the problem is related to operational difficulties and the effectiveness of relevant legislation.

First, there is no specific law dedicated to combating discrimination in the labour market. The labour market is, from the perspective of the works, legally framed through three broad categories and two labour regimes: employees (hired by companies, and regulated by the Chinese Labour Law), public servants (selected by the State, and regulated by the Chinese Public Servants Act), and officials of public institutions (organizations that provide public services, such as education, culture, hygiene etc., established by public bodies and other entities with state resources, regulated by the Labour Law or the Chinese Public Services Act). Both workplaces, however, have their problems regarding discrimination.

In the case of the regime established by the Chinese Labour Law, its applicability is restricted to employees and companies that are contractually bound (Article 2). ${ }^{69}$ Thus, despite its various provisions prohibiting discriminatory practices, none of them can be used as grounds to start a lawsuit against the discriminating company when the acts occur precisely at the time of hiring, given the absence of contractual bound. The hermeneutical inadequacy of this understanding is evident, as there is a concentration of discriminatory practices precisely at the contracting stage. Denouncing such a state of things is the absence of any reference to pre-contractual situations in all lawsuits brought for labour discrimination between 2000 and 2011..$^{70}$

As Jiefeng Lu's studies reveal, a similar pattern is perceptible with regards to public service. Once more, discrimination occurs primarily in the recruitment process, with many of the characteristics required and evaluated having no relation to the service itself, such as age, height, appearance, marital status, political affiliation, and so on. However, unlike the previous situation, a female victim of discrimination may bring an action against the government on the basis of Article 2 of the Administrative

many children have dropped out of school, with the author referring to data from 1990, when 4.8 million children, mostly from rural areas, dropped out, of whom $80 \%$ were girls. It corroborates with these results a governmental report cited by the author, in which it is pointed out that among the illiterate and semi-illiterate in China up to the year 1994, 70\% are women. These trends are repeated at the higher level, with women being able to compete for only a third of university seats (Cf. Han, "Holding-up more than half the sky", 791-810).

${ }^{67}$ Cf. Jiefeng Lu, "Regulating employment discrimination in China: a discussion from the socio-legal perspective," Michigan State International Law Review, v. 23, No. 2 (2015): 437-457.

${ }^{68}$ According to a survey conducted by the University of Political Science and Law of China, 85.5\% of respondents said they had experienced discrimination, $50.5 \%$ said that discrimination was a serious matter, and only $6.6 \%$ said there was no discrimination in China. ( $\mathrm{Lu}$, "Regulating employment discrimination").

${ }^{69}$ People's Republic of China, Labour Law of the People's Republic of China, Jan $5^{\text {th }}$, 1994, retrieved from http://www.npc.gov.cn/englishnpc/Law/2007-12/12/content_1383754.htm.

${ }^{70}$ Cf. Jiefeng Lu, "Employment Discrimination in China: The Current Situation and Principle Challenges," Hamline Law Review, No. 1, (2009). 
Procedure Law of the People's Republic of China,${ }^{71}$ which provides that any citizen, legal entity, or organization has the right to prosecute the government or government agencies, as long as the violation of their rights and interests is demonstrated by a "concrete administrative action". Most courts, according to Jiefeng Lu, have refused such lawsuits, arguing that recruitment is not a "concrete administrative action". 72

Zhou Wei considers symptomatic of the described state of affairs the invariable reference to Article 33 (2) of the 1982 Constitution as the legal ground for all actions against discriminatory practices (including those relating to gender discrimination, regardless of the specific provisions in the Constitution, such as Article 48). Considered by the Chinese legal scholars as the "equality protection clause", 73 it reads: "All citizens of the People's Republic of China are equal before the law (...). Every citizen is entitled to the rights and at the same time must perform the duties prescribed by the Constitution and other laws. "" However, the judiciary in China is heavily influenced to ignore the constitutional text, whether in its decisions or as grounds for the enforceability of rights. Moreover in China, the horizontal efficacy of fundamental rights (understood as its direct applicability to relations established between individuals) is not a pacified matter, with a considerable part of the constitutional scholarship arguing for the inapplicability of the constitutional text in disputes between individuals. ${ }^{75}$

Therefore, given the absence of institutionalization in China of the possibility of public discussion on discrepancies between the fundamental rights guaranteed in the constitutional text and the particular interpretation of them made in the public policies determined by the National People's Congress and the Council of State, it is difficult to see how such rights of dignity would be characterized by the necessary enforcement. There presupposed the ability to assert itself, through due process, including the interpretation of women regarding their rights, in the public debate.

\section{V.The situation of gender inequality and discrimination against women in Brazil}

The Brazilian culture towards women is constituted of several hierarchies inherited from multiple origins, as Catholic doctrine and Iberian culture. Marked by patriarchal structures, the positions to be assumed and performed by each gender are intimately linked to sexual and family life, with the role of women associated to their reproductive circle and their relationship with a man, the head of the family. Thus, mainly and socially, women are expected to assume the roles of wives, mothers and housekeepers. ${ }^{76}$

Until recently, such a horizon of meaning had a decisive influence on the country's legislative production, as, for example, the numerous restrictions on working

\footnotetext{
${ }^{71}$ People's Republic of China, Administrative Procedure Law of the People's Republic of China, April $4^{\text {th }}$, 1989, retrieved from: http://www.china.org.cn/english/government/207336.htm.

${ }^{72}$ Cf. Lu, "Employment Discrimination in China: The Current Situation".

${ }^{73}$ Cf. Zhou Wei, Constitutional Basic Rights and the Judicial Remedy (Beijing: The People's Public Security University of China Press, 2003).

${ }^{74}$ People's Republic of China, China's Constitution of 1982 with Amendtments through 2004, March 14 ${ }^{\text {th }}$, 2004, retrieved from: https://www.constituteproject.org/constitution/China_2004.pdf?lang=en.

${ }^{75}$ Cf. Lu, "Employment Discrimination in China: The Current Situation".

${ }^{76}$ H. Onsrud, S. Paixão and S. Nichols, Women and Land Reform in Brazil. [Technical report n. 239] (Canada: Department of Geodesy and Geomatics Engineering - University of New Brunswick, 2005).
} 
conditions and roles available to women. ${ }^{77}$ In this sense, the Federal Constitution of 1988 is rightly hailed as an undisputed landmark of rupture, by explicitly assuming equality between the sexes, giving rise to a series of public policies aimed specifically at the achievement of this equality in the labour sphere. On the other hand, despite the merits of the constitutional text, especially with regards to domestic violence, and even related to inequality of payment or of labour market participation, many have been the difficulties for its effectiveness in Brazilian society. Thus, until recently, both women and violence practised against them were relegated to the intimacy of the house, a perception that, even after 1988, took time to be extirpated from legal texts and is still present in the legal mindset of judges and public administrations, notwithstanding the mentioned advancements.

Symptomatically, Brazil, in 2017, occupied the $79^{\text {th }}$ position in the ranking structured based on the Gender Inequality Index calculated by the United Nations. Only $11.3 \%$ of parliamentary seats were held by women in 2017 . However, $61 \%$ of women had at least second-degree education, compared to $57.7 \%$ of men from 2010 to 2017. Yet and paradoxically, only $53.2 \%$ of the female labour force was inserted in the labour market in 2017 , against $74.7 \%$ of the male labour force. ${ }^{78}$

Violence against women is a major issue in the Brazilian scenario of gender inequality. Between 1980 and 2010, it is estimated that 92,000 women were murdered in Brazil. If at first glance, these deaths seem to be of little significance within a universe of which they represent only $10 \%$ of the total number of murders, according to Stela Nazareth Meneghel and Vania Naomi Hirakata, it must be taken into account that of this whole, $42 \%$ occurred in domiciliary environments, against $14 \%$ of male deaths. Corroborating these data, of the 51,000 cases reported in hospitals by women victims of physical violence in $2011,22 \%$ of the culprits were fathers of the victims, and $15 \%$ were current or former partners. ${ }^{79}$

These numbers, therefore, persist, despite the context of 20 years of public policies specifically aimed at combating violence against women. This persistence, to some extent, is still partially explained by normative-institutional errors and deficiencies of the public choices made in this period. Those choices are organized in five legal frameworks, namely, Laws No. 9.099/1995, 10.455/2002, 10.778/2003, 10.886/2004, and $11.340 / 2006$.

The first one created specialized courts for crimes of small offence (which, in general, are defined in the Brazilian legal system by reference to the duration of the penalty legally ascribed to crime practices), introducing the possibility of reconciliation between victim and aggressor, as well as the conditional suspension of the legal prosecution. Because most of the charges related to domestic violence involve criminal conducts which are punishable by deprivation of liberty for up to two years, a significant number of these cases began to be tried before the mentioned specialized courts, mostly resulting in criminal transactions, without conviction.

As Ana Lucia Sabadel and Dimitri Dimoulis have pointed out, the lack of preparation of judges has become notable, especially regarding issues about gender.

\footnotetext{
${ }^{77}$ Cristiane Maria Sbalqueiro Lopes, "Direito do trabalho da mulher: da proteção à promoção," Cadernos Pagu v. 26 (2006): 405-430.

${ }^{78}$ United Nations (UN), Gender Inequality Index, 2017, retrieved from: http://hdr.undp.org/en/ composite/GII.

${ }^{79}$ Stela Nazareth Meneghel and Vania Naomi Hirakata, "Femicides: female homicide in Brazil," Revista Saúde Pública v. 45, No. 3 (2011).
} 
There is a considerable amount of inadequate solutions, with victims being forced to accept derisory indemnities, and some disparate decisions, which condemned the accused to take the victim to dinner or to give her flowers. From the mapping of decisions, the authors perceive a "reprivatization" of conflicts, reinforcing the patriarchal idea that they are concerned only with the parties involved. ${ }^{80}$

The two successive legislative innovations came with the purpose to adapt the procedures of previous legislation to the reality of domestic violence, but with little success. In the first case, Law No. 10.455 introduced the possibility of adopting preventive measures to remove the accused from the victim's home. However, by leaving the concept of domestic violence undefined, part of the judiciary refused to apply the measure, based on the principle of legality (nullum crimen sine lege certa). In the second case, Law No. 10.778 obligated public and private health service officials to inform legal authorities whenever they noticed imprints of domestic violence in their patients, in addition to the establishment of a definition of the legal concept, in consonance with the provisions of the Inter-American Convention on the Prevention, Punishment, and Eradication of Violence against Women, ratified by Brazil since 1995.

With Law No. 10.886, legislature sought to create a qualification of personal injury, linking it to the practice of domestic violence, albeit from a gender-neutral perspective, and with the absence of any alternative measures, reinforcing the understanding that the solution to the problem would be criminal prosecution. In 2006, however, with the promulgation of Law No. 11.340, known as the "Lei Maria da Penha", the first Brazilian law to systematically dispose of domestic violence, it is assumed that at the legislative level, the importance of women as victims of domestic violence, which corresponds to the creation of non-criminal measures and the reassignment of jurisdiction regarding domestic violence cases, from the already mentioned courts for crimes of small offence to courts specialized in domestic violence.

It is possible to say that on the legislative level "Maria da Penha Law" meant an almost integral absorption and translation of Brazilian feminist movements' demands. However, when applied, controversies surrounding it had restrictive consequences, as Cecilia MacDowell Santos points out. In its early years, many judges ruled the statute as unconstitutional, because of the distinction between men and women, which, in their opinion, was unacceptable in face of the right to equality, while others continued to affirm domestic violence cases as crimes of small offence. A series of contradictory decisions directed the issue to the Federal Supreme Court, which resolved these questions ambiguously, from the perspective of feminist movements. This was so, because what should have been recognized from the start by Brazilian judges, began to be observed by an imposition of the Supreme Court. ${ }^{81}$

In the end, it is perceived that the hierarchical understanding of the relations between men and women has a considerable diffusion, encompassing state agents and informing legal and social interpretations of domestic violence as a private problem. In spite of advances, including the scope of media campaigns encouraging legal action against violators, there is still much to be done.

\footnotetext{
${ }^{80}$ Ana Lucia Sabadell and Dimitri Dimoulis, "Domestic Violence in Brazil: social problems and legislative interventions," Research Paper Series - Legal Studies (2014).

${ }^{81}$ Cecília MacDowell Santos, "Da delegacia da mulher à Lei Maria da Penha: Absorção/tradução de demandas feministas pelo Estado," Revista Crítica de Ciências Sociais v. 89 (2010): 153-170. Cf. Supremo Tribunal Federal, Jurisprudência do STF é destaque nos 10 anos da Lei Maria da Penha, retrieved from: http://www.stf.jus.br/portal/cms/verNoticiaDetalhe.asp?idConteudo= 322468 .
} 
As denounced by the Gender Inequality Index, women in Brazil also face discrimination in the labour market, in the form of a vicious cycle common to developing countries, starting with the low level of schooling, which prevents them from reaching positions that require higher education, which forces them to seek employment in the services sector or in the informal market. ${ }^{82}$ In a report to the Committee on Economic, Social and Cultural Rights, it was pointed out that in 2001 $7 \%$ of the country's women never attended a school, $60 \%$ did not reach high school, with only $10 \%$ of that number having finished first grade, while studies say the dropout rate among women was around 18\%. 27\% attended high school, but only $16 \%$ of this total finished it. Only $6 \%$ of women enrolled in higher education and only 3\% completed it. Only $1 \%$ of Brazilian women were in postgraduate courses (probably less than $0.2 \%$ in doctoral courses). ${ }^{83}$

Although these numbers have improved significantly in ten years, some discrepancies are still present, especially in the following areas: employment, wage gains, and occupancy of leadership positions in organizations and companies. Overall, in 2004, only $30.5 \%$ of CEO positions were held by women, concentrated in areas such as education and social security. And in 2007, according to Maria Cristina Aranha Burschini, wage gaps between men and women increased as the study time increased, given that among men and women with 15 or more years of schooling (corresponding to a higher education course), $62 \%$ of men received more than five minimum wages, against $35 \%$ of women. ${ }^{84}$

As suggested above, women are still typically and culturally tied to their reproductive cycle, seen primarily as responsible for performing functions related to motherhood, ${ }^{85}$ culminating in the disparate indices of domestic activities performed by each partner or spouse of heterosexual couples. ${ }^{86}$ Just as importantly, such stereotypes extend themselves to the public space, partially contributing to the lack of political representation of women in the Brazilian state.

Since 1998, Brazil has adopted mandatory quotas (at least 30\%) for women candidates at all levels of the Federation. This measure was approved without much debate or controversy. At the time, the feminist movement itself was divided, on one hand seeing it positively, and on the other questioning its capacity for effectiveness. According to Clara Araujo, the meager results are not only caused by the country's electoral system. For the author, based on a comparative analysis of other Latin American countries with similar cultural backgrounds adopting mandatory quotas, the lack of representation has cultural and economic causes.

First, women candidates face serious difficulties in raising funding for their campaigns, which is explained both by the discrepancies in the economic market and by their absence in prominent positions, either in the private or in the public sector. Second, the absence of any mechanisms of control regarding political parties' composition and functioning helps to perpetuate their formation, generally composed

\footnotetext{
${ }^{82}$ Naercio Menezes Filho and Luiz Scorzafave, Employment and inequality outcomes in Brazil, 2007, retrieved from: https://www.oecd.org/employment/emp/42546065.pdf.

${ }^{83}$ Committee on Economic, Social and Cultural Rights, Violence against Women in Brazil: A report to the Committee on Economic, Social, and Cultural Rights, May 23, 2003, retrieved from: http:/ /www.omct.org/ files/2004/07/2409/eng_2003_02_brazil.pdf.

${ }^{84}$ Maria Cristina Aranha Bruschini, "Trabalho e gênero no Brasil nos últimos dez anos," Cadernos de Pesquisa v. 37, No. 132, (2007): 537-572.

${ }^{85}$ Onsrud, Paixão and Nichols, Women and Land Reform in Brazil.

${ }^{86}$ Bruschini, "Trabalho e gênero no Brasil".
} 
by men, which uphold stigmatized visions about women, with politics appearing as a virile and masculine activity. These factors influence the presentation of candidature lists, since the quota for women is based on the maximum number of applications that each party can offer (up to $15 \%$ of available positions). As parties are not required to submit the maximum number of candidates, there are few lists that reach the legal minimum of female candidates. ${ }^{87}$

Therefore, it is evident that women and the problems they face still have reduced official and public space in Brazil, despite the undeniable progress. The cultural expectation of most men (and a significant conservative portion of women themselves) is still that women should remain at home (the place par excellence for resolving any and all conflicts in which women are involved) or divide their lives between house and job but, taking care of their families' home first. Despite the existence of numerous legislative measures and specific public policies, apart from the constitutional mandates of gender equality, Brazil's entrenched culture hinders - socially and legal-institutionally - the realisation of the fundamental rights of women's dignity. From the point of view of subsistence conditions, (see the analyses about the working conditions of the woman) expressiveness, (see the difficulties of being heard that we present in this study), empowerment conditions, (see the analyses of the place occupied by women in public positions) and conditions of respect (see explanations on the difficulties of combating domestic violence in Brazil), all dimensions of dignity and the promotion of women's rights still require significant advances.

\section{Final considerations}

The research undertaken here, in a comparative perspective on women's rights and gender inequality still existing in BRICS countries, as any research that wants to deal with the problem of the effectiveness of fundamental rights, cannot be developed by the traditional perspective of Comparative Law (characterised by the comparative relationship between abstract norms, or at most between scholar explanations of these abstract norms, from different countries), but from a perspective of interconstitutional studies, critically guided to understand the concrete juridical experience of a society, beyond its nomological dimension. In addition, it sought to overcome the superficialities of purely external readings of a county's juridical-constitutional experience, which occurred with an exploratory analysis of sociological, economic and cultural research on the status of women in BRICS countries.

As for Russia, the confrontation of Russian constitutional nomology and its constitutionalist discourse with the concrete practices of women's rights allowed us to consider that there is a conservative and patriarchal tendency dominating the juridical experience of that country, which significantly influences the unequal treatment of women in the country. Thus, a State skeptical about the Western human rights discourse is fed by a distrustful constitutional literature skeptical of the same discourse and determined to find alternatives in the Russian cultural traditionalism to ground its constitutional system. In our view, these are the main reasons (in addition to the country's size and complexity, and to the recent radical transformation it has undergone, given the changing political and economic regimes, among others) for the existence of the aforementioned gap between the presence of an official discourse of dignity and

\footnotetext{
${ }^{87}$ Clara Araújo, "As cotas por sexo para a competição legislativa: o caso brasileiro em comparação com experiências internacionais," Dados v. 44, n. ${ }^{\circ} 1$ (2001).
} 
respect for women in Russian constitutional nomology (although, comparatively, law and public opinion in Russia are themselves less enthusiastic about dignity rights when compared to the other countries here discussed) and its effectiveness.

When we confronted India's official constitutional nomology with the actual practices and concrete data on the situation of Indian women, it was possible to confirm the important disparities between official normativity and the perpetuation of certain traditional and religious experiences, ultimately resulting in a large gap between what is stated in its laws and the effectiveness of public policies and governmental practices of protection and enforcement of women's rights. We also find a peculiar intensification of this discrepancy in the territorial interiorization, when the deep parts of India charge their price, perpetuating practices of discrimination and violence through the country's continental dimensions.

The study of the concrete situation of gender inequality in China, has shown, for its turn, that the performative act of declaring rights in the Chinese nomological plan does not necessarily imply the guarantee of their enforceability as rights in concrete situations. It was found that the difficulty women face in China for the protection of their rights is notorious. In the analysis of the situation of women in Chinese territory, it was noted the existence of bureaucratic instructions and regulations inconsistent with or blinded to the enforceability of non-discrimination and protection rights provided by the Constitution make these rights practically unclaimable when incorrectly handled by the State.

Thus, there is also a gap between the declaration and promotion of women's rights in China. This gap, however, is not the same as in Brazil, for example, where, as we have seen, rights are declared and these declarations are confirmed in infraconstitutional plans, but nevertheless they are hermeneutically misrepresented at the level of state bureaucracy and private relations, in a way that they are not respected or enforced. The Chinese case is not of a country that does not comply with its laws (as it seems to be in the Brazilian case). The Chinese case is the case of a country that complies with its laws, but sees its duties therein envisaged as superior and prior to its rights, and administrative and bureaucratic regulations as the main milestones, where the Constitution is only a symbol of a new utopia (one of full economic development), whose pursuit justifies and legitimates day-to-day rules that contradict the constitutional utopia itself, being among them the indifference towards women discrimination. Finally, in a certain way, the analyses made about Brazil demonstrate that there is a recent advance in the country, but it is still below the minimum that is expected to constitute a society free of prejudice and gender violence. 